\title{
TRANSAKSI JUAL BELI PRODUK IMPOR TELEMATIKA DAN ELEKTRONIKA DALAM PERSPEKTIF UNDANG-UNDANG PERLINDUNGAN KONSUMEN
}

\author{
Putu Wilang Prayoga, I Nyoman Sujana, Ida Ayu Putu Widiati \\ Fakultas Hukum Universitas Warmadewa, Denpasar-Bali, Indonesia \\ wilang209@gmail.com, nyomansujanaa2015@gmail.com, idaayuputuwidiati@gmail.com
}

\begin{abstract}
Abstrak
Saat ini, banyak produk impor telematika dan elektronika yang akan dipasarkan di dalam negeri tidak memenuhi syarat, maka dengan itu diperlukannya peraturan hukum untuk melindungi kepentingan konsumen. Dalam penelitian ini berfokuskan pada perlindungan hukum terhadap konsumen terkait perdagangan produk impor telematika dan elektronika berdasarkan Undang-undang Nomor 8 Tahun 1999 tentang Perlindungan Konsumen. Penelitian ini bertujuan untuk menganalisis pengaturan transaksi jual beli produk impor telematika dan elektronika di Indonesia dan mengkaji perlindungan hukum terhadap konsumen dalam transaksi jual beli produk impor telematika dan elektronika dalam hal terjadinya wanprestasi. Penelitian ini didesain dengan penelitian hukum normatif dengan pendekatan Perundan-undangan. Sumber data yang digunakan adalah data primer dan sekunder. Hasil penelitian menunjukkan bahwa pengaturan terkait perdagangan produk impor telematika dan elektronika diatur dalam Peraturan Menteri Perdagangan Nomor 38 Tahun 2019. Sesuai dengan perlindungan konsumen, pelaku usaha yang merugikan konsumen dengan sengaja dapat dikenakan pasal 60 yang dikenakan sanksi administratif.
\end{abstract}

Kata Kunci: Produk impor, Transaksi Jual Beli, Telematika dan Elektronika, Perlindungan Konsumen.

\begin{abstract}
The amount of import of telematics and electronic products which will be marketed in the country do not qualify, then the need for legislation to protect consumer interests. In this research, a focus on the legal protection of trade-related consumer telematics and electronic products imported by Law - Act No. 8 of 1999 on Consumer Protection utilizing formulation of the problem is I. How will the buying and selling of imported telematics and electronic products in Indonesia? 2. How is the legaJ protection for consumers in buying and selling transactions of imported telematic and electronic products in the event of default. The research objective is to know about buying and selling arrangements related to the import of telematics and electronic products in Indonesia and to be useful for people, especiaJly consumers. The method used is normative legaJ research. The research result of trade-related settings telematics and electronic products imported regulated in the Trade Minister Regulation No. 38 of 2019. Following the protection of consumers, businesses that harm consumers by deliberately being subject to Article 60 are subject to administrative sanctions.
\end{abstract}

Keywords: Buying and Selling Transactions Imported Products Telematics and electronics Consumer Protection.

\section{PENDAHULUAN}

Zaman yang semakin berkembang ini membuat semua Negara berlomba-lomba untuk mengeluarkan inovasi terbaru sesuai dengan kebutuhan dan perkembangan zaman, salah satunya yaitu produk telematika dan elektronika. Barang tersebut selalu mengalami perubahan dalam perkembangannya yang mengharuskan manusia lebih cermat dan teliti dalam membeli suatu produk agar tidak mengalami kerugian yang besar. Dalam penjualan kemungkinan besar di salah satu produk terdapat cacat yang disembunyikan oleh pelaku usaha guna bertujuan agar produk cacat tersebut ada yang 
membeli karena kurang cermat dan teliti, dan juga pelaku usaha ingin menghindari kerugian yang lebih besar sehingga melakukan segala cara agar produknya dapat terjual kepada konsumen. Produk Telematika dan Elektronika yang diperdagangkan hampir semua memiliki izin untuk dijual secara resmi, tetapi seiring perkembangan jaman yang modern ini banyaknya terjadi persaingan tidak sehat dimana pelaku usaha menginginkan agar produknya cepat laku dan harga tidak terlalu rnahal dengan cara pelaku usaha mengedarkan produknya secara ilegal melalui pasar gelap ke seluruh pasar gelap yang ada termasuk ke pasar gelap yang ada di Indonesia juga tak luput dari hal itu.

Pasar gelap atau sering disebut dengan black market yaitu merupakan pasar yang memperjualbelikan produk ilegal yang didatangkan dari luar negeri. Arti ilegal yang dimaksud yaitu bahwa barang yang masuk ke indonesia yairu barang dari luar negeri dengan tidak melakukan proses pemasukan barang sesuai aruran yang berlaku atau masuk dengan cara paksa tanpa adanya perizinan (Siti Amalia, 2020). Dalam proses jual beli di pasar gelap dimana semua proses sampai terjadinya transaksi itu dilakukan dibawah tangan dan bertentangan dengan hukum yang berlaku, pelaku usaha yang menjual barangnya di pasar gelap juga dapat dikatakan dengan pelanggaran hukum perdata dan hukum pidana. Dengan penyelundupan produk yang begitu marak dilakukan oleh pelaku usaha yang curang, sudah jelas negara dirugikan banyak dan rakyat pun ikut dirugikan dalam hal ini (Kamasa, 2014). Maka diperlukannya hukum yang mengatur secara khusus terhadap tindak kejahatan tersebut. Hukum diperlukan agar negara tidak banyak mengalami kerugian akibat banyaknya pelaku yang melakukan perdagangan ilegal di pasar dalam negeri, selain merugikan negara, rakyat pun akan ikut dirugikan dalam hal jika kurang cerrnat membeli produk yang diperoleh dengan harga yang tidak wajar sehingga masyarakat tergiur untuk membelinya dan setelah membelinya bisa saja produk tersebut sudah cacat dari awal pembuatan hanya saja disembunyikan dengan baik, dan setelah ingin mengembalikan barang karena produk tersebut adalah produk ilegal maka dari itu produk tersebut tidak mendapatkan garansi kembali. Perlindungan konsumen yaitu salah satu hal yang penting dalam suatu proses berbisnis (Hamid, 2017). Saat akan menjalankan suaru usaha yang jujur didalamnya ada kesetaraan hukum pada pemerintah dan kedua pihak yang melakukan bisnis, tidak seimbangnya perlindungan hukum terhadap konsumen dapat menyebabkan pihak konsumen di posisi yang tidak menguntungkan. Dalam posisi yang tidak menguntungkan atau dalam posisi lemah ini, dapat menyebabkan konsumen mengalami kerugian. Kerugian ini dapat terjadi dikarenakan adanya perjanjian hukum antara produsen dan konsumen, dan juga dikarenakan pelaku usaha yang melakukan perbuatan melanggar hukum. Agar tidak terjadinya hal yang merugikan konsurnen lebih banyak Jagi maka disahkannya Undang-undang Perlindungan Konsumen yang dijadikan sebagai pengikat terhadap peraturan yang tersebar (Miru, 2013).

Walaupun sudah ada hukum yang berlaku tetap saja masih ada pelaku usaha yang tetap melakukan perdagangan ilegal demi mencari keuntungan lebih, padahal jelas-jelas hukum sudah melarang untuk melakukan perdagangan ilegal untuk produk impor. Banyak Peraturan hukum yang berlaku di Indonesia dan diaturnya sudah jelas hanya saja pelaksanaan penegakan hukumnya yang belum sesuai dengan peraturan hukurn tersebut. Tentunya peran dinas bea dan cukai termasuk kepolisian sangat berperan penting dalam mengawasi dan menangani tindak pidana perdagangan ilegal dan selanjutnya menindak dengan tegas pelaku agar negara tidak mengalami kerugian akibat pelaku usaha yang bermain curang. Sehingga perlindungan untuk konsumen mendapat perhatian. Karena masih banyak munculnya barang impor telematika dan elektronika yang tidak bersamaan dengan kualitasnya yang bisa merugikan konsumen dan masih adanya pelaku usaha yang berbuat curang tersebut yang melatar belakangi. Maka dilakukan penelitian yang bertujuan untuk bertujuan untuk menganalisis pengaturan transaksi jual beli produk impor telematika dan elektronika di Indonesia dan mengkaji perlindungan hukum terhadap konsumen dalam transaksi jual beli produk impor telematika dan elektronika dalam hal terjadinya wanprestasi

\section{METODE PENELITIAN.}

Untuk mendapatkan data yang benar terkait dengan permasalahan yang telah diuraikan di atas, dalam penelitian ini tipe penelitian menggunakan metode penelitian hukum normatif (Bambang, 2002). Memakai metode hukum normatif untuk mempermudah mendapatkan informasi dengan data yang didapat sangat akurat dan tepat. Dalam penelitian hukum normatif ini menggunakan pendekatan Perundang-undangan sebagai pendekatan masalah yang dimana peneliti mengkaji peraturan perundang - undangan dengan berkaitan pada masalah yang ada. Dan juga menggunakan bersifat 
konseptual artinya penelitian ini juga mengkaji pandangan atau pendapat doktrin yang setelahnya akan memunculkan ide tentang pengertian hukum dan konsep hukum yang relevan dan tepat. Data diperoleh menggunakan teknik kepustakaan sebagai upaya untuk meraih dan mendapatkan dokumen atau bahan untuk penelitian dalam bentuk tertulis yang meliputi bahan hukum primer yaitu bahan hukum yang terdiri dari peraturan perundang-undangan UU No.8 Tahun 1999 tentang Perlindungan Konsumen, Peraturan Menteri Perdagangan Nomor 38 Tahun 2019 Tentang Ketentuan Petunjuk Penggunaan dan Jaminan Layanan Puma Jual Bagi Produk Elektronika dan Produk Telematika. Bahan hukum sekunder yaitu bahan hukum yang akan mengulas isi bahan hukum primer yang berupa buku literatur, artikel, dan juga karya ilmiah lainnya yang masih terkait dengan penelitian . Dalam penelitian ini analisis bahan hukum yang digunakan adalah deskriptif-kualitatif, dengan menguraikan data yang diperoleh yang didasarkan pada teori hukum untuk mendapatkan kesimpulan yang signifikan, dan menggunakan analisis bahan hukum mensistematisasi dan menafsirkan bahan hukum yang sudah dikumpulkan agar memudahkan untuk menganalisisnya (Sugiyono, 2013).

\section{HASIL DAN PEMBAHASAN}

1. Pengaturan Transaksi Jual Beli Produk Impor Telematika dan Elektronika di Indonesia.

Pengaturan transaksi jual beli harus dilandasi dengan hukum agar transaksi jual beli tersebut aman dan dilindungi oleh hukum yang mengatur. Terkait dengan transaksi jual beli sebelum terjadinya transaksi jual beli diperlukannya kesepakatan atau perjanjian antara kedua belah pihak. Tujuannya yaitu agar kedua belah pihak sama diuntungkan karena sudah ada perjanjian terlebih dahulu sebelum dilakukannya transaksi, dengan adanya perjanjian atau kesepakatan maka konsumen dan pelaku usaha tidak perlu khawatir jika terjadi hal yang tidak diinginkan. Adapun syarat sahnya perjanjian menurut Kitab Undang-undang Hukum Perdata (KUH Per) dalam pasal 1320 yaitu

untuk sahnya persetujuan diperlukannya empat syarat yaitu sepakat mereka yang mengikatkan diri, kecakapan untuk membuat suatu perikatan, suatu hal tertentu dan suatu sebab yang halal. Untuk syarat yang pertama adanya kata sepakat. dalam perjanjian jual beli ini sebelum terjadinya transaksi jual beli pelaku usaha dan konsumen telah sepakat terlebih dahulu untuk menjual atau membeli suatu barang telematika atau elektronika tersebut tanpa ada paksaan dari pihak penjual. Syarat yang kedua yaitu kecakapan, dalam hal ini cakap yang dimaksud adalah kecakapan dalam umur yang artinya bahwa konsumen yang akan membeli produk telematika dan elektronika tersebut harus dikatakan dewasa. Maka dalam sebuah transaksi barang telematika dan elektronika biasanya saat akan terjadinya transaksi jual beli pihak pelaku usaha akan meminta kartu pengenal atau ktp untuk menjadi jaminan bahwa konsumen yang akan membeli barang tersebut sudah cakap dalam umur. Syarat yang ketiga yaitu suatu hal tertentu, yang artinya adanya sebuah objek atau barang yang diperjanjikan. Dalam transaksi jual beli ini pelaku usaha dan konsumen sepakat membuat perjanjian dengan barang yang diperjanjikan yaitu barang telematika dan elektronika tersebut, maka suatu perjanjian bisa dilakukan. Terakhir suatu perjanjian tidak boleh memperjanjikan sesuatu yang dilarang oleh Undangundang dan hukum. Dalam transaksi jual beli ini dikarenakan yang diperjanjikan adalah produk telematika dan elektronika yang wajar maka hat tersebut dapat dijadikan syarat untuk sahnya suatu perjanjian.

Setelah adanya suatu perjanjian antara pihak pelaku usaha dan pihak konsumen, maka transaksi jual beli tersebut dapat dilaksanakan dan jika setelah terjadinya transaksi jual beli tersebut timbul masalah maka konsumen dapat meminta pelaku usaha untuk mengecek barang yang dibelinya entah itu akan diganti rugi atau kerusakan tersebut dikarenakan konsumen yang salah dalarn memakainya. Pengaturan terkait perdagangan produk impor telematika dan elektronika di Indonesia sudah ada hukum yang mengaturnya (Suparji, 2014). Pembatasan dan larangan perdagangan barang dan jasa sudah ditetapkan oleh pemerintah untuk melindungi keamanan negara. Sehingga dalam perdagangan produk impor telematika dan elektronika diatur di dalam Permendag No.38 tahun 2019 tentang ketentuan petunjuk penggunaan dan jaminan layanan puma jual bagi produk telematika dan elektronika yang pada pasal 2 ayat ( I) menjelaskan setiap produsen atau importir wajib melengkapi setiap produk elektronika dan produk telematika dengan petunjuk penggunaan dan kartu jaminan dalarn bahasa indonesia sebelum diperdagangkan di pasar dalam negeri sehingga pelaku usaha yang akan memperdagangkan produk impor khususnya telematika dan elektronika wajib melengkapi dan mematuhi aturan yang berlaku. Tujuannya diharuskan untuk mengisi cara penggunaan dan informasi 
dalam bahasa Indonesia yaitu agar menjamin konsumen mendapatkan haknya atas informasi yang benar dan jelas.

\section{Perlindungan Hukum Terhadap Konsumen dalam Transaksi Jual Beli Produk Impor Telematika dan Elektronika.}

Dalam kegiatan perdagangan di Indonesia sudah sering sekali terjadinya kecurangan yang dilakukan oleh pihak pelaku usaha, banyak sekali kecurangan yang dilakukan guna untuk mendapatkan keuntungan yang ban yak dari barang yang mereka jual, ada yang hanya merugikan sedikit konsumen dan hampir semua barang yang dibeli oleh konsumen. Pelaku usaha melakukan hal curang tersebut salah satunya agar barang mereka cepat laku dan memperoleh uang yang banyak, seperti menyisi pkan barang yang rusak diantara barang yang masih bagus dengan harapan konsumen membeli barang tersebut. Adapun faktor terjadinya kecurangan pelaku usaha dalam kegiatan perdagangan yaitu:

1. Ekonomi

Faktor yang sangat mempengaruhi pelaku usaha melakukan kecurangan, dikarenakan barang mereka tidak laku di pasaran maka akhimya merekapun melakukan kecurangan dalam memperdagangkan barang yang dijualnya seperti menyisipkan produk cacat diantara produk yang bagus, menyelundupkan barang dari luar negeri ke dalam negeri guna menghindari pajak masuk.

2. Adanya Peluang

Faktor yang dapat membuat pelaku usaha melakukan kecurangan. Dikarenakan adanya peluang pelaku usaha dapat dengan mudah untuk melakukan kecurangan terhadap konsumen, yang dimana konsumen yang kurang cermat dan teliti membuat peluang sernakin besar.

3. Lemahnya Pengawasan

Selain kedua faktor diatas, lemahnya pengawasan oleh pemerintah juga dapat dimanfaatkan oleh pelaku usaha untuk berbuat curang. Dikarenakan tidak adanya pengawasan yang ketat pelaku usaha dapat dengan mudah memasukkan barang ilegal ke pasar dalam negeri yang dimana hal tersebut juga berdampak pada konsumen yang membeli barang tersebut. Salah satu kecurangan yang dapat dilakukan pelaku usaha yairu wanprestasi. Dalam hal ini yang dimaksud yaitu setelah pelaku usaha dan konsurnen sepakat melakukan perjanjianjual beli dan setelah itu barang yang dibeli konsumen terjadi kerusakan dikarenakan barang yang dibeli ada cacat yang tidak terlihat pelaku usaha akan tidak memberikan ganti kerugian dan akan menyalahkan konsurnen atas kerusakan tersebut. Wanprestasi terjadi diawali dengan adanya perjanjian terlebih dahulu, Perjanjian dibuat untuk mengatur hukum dalam pembuatan kontrak (Yahman, 2014).

Dalam hal ini hukum diperlukan untuk melindungi konsumen agar tidak banyak yang dirugikan (Zulham, 2017). Pengertian konsumen dibagi 3 yaitu konsurnen komersial, konsurnen antara, konsurnen akhir. Walaupun pengertian konsurnen dibedakan menjadi 3 tetapi tetap saja dikatakan konsumen. Untuk melindungi Hak konsumen maka dibuatkanlah Undang - Undang Nomor 8 Tahun 1999 tentang Perlindungan Konsumen. salah satu yang dijelaskan pada 19 yaitu pelaku usaha harus bertanggung jawab terhadap konsumen yang mengalarni kerusakan atas barang yang dibelinya dengan rnengganti kerugian. Tetapi jika pelaku usaha dapat membuktikan bahwa kerusakan yang dialarni konsumen itu karena konsumen sendiri maka pelaku usaha tidak perlu bertanggung jawab mengganti kerugian, jika pelaku usaha tidak dapat membuktikan hal tersebut maka sesuai dalam pasal 60 pelaku usaha dapat dikenakan sanksi administratif yaitu mengganti kerugian dengan paling banyak Rp. $200.000 .000,00$

Untuk melindungi Konsumen agar tidak mengalami kerugian di dalam UUPK juga mengatur pelarangan terhadap pelaku usaha terkait hal yang tidak boleh dilakukan. Pelarangan terhadap pelaku usaha terkait hal yang tidak boleh dilakukan tersebut diatur pada Bab IV Perbuatan yang dilarang bagi pelaku usaha pasal 8, pasal9,pasal 10,pasal 11,pasal 12, pasal 13,pasal 14, pasal 15,pasal 16, danpasal 17. Salah satu pasal yaitu pasal 8 ayat (I) huruf j yang menyatakan (I) Pelaku usaha dilarang memproduksi atau memperdagangkan barang atau jasa yang tidak mencantumkan informasi dan petunjuk penggunaan barang dalam bahasa Indonesia sesuai dengan ketentuan Perundang-undangan yang berlaku.

Dalam hat ini dirujukan untuk melindungi konsumen agar tidak salah dalarn memakai barang dan pelarangan ini dimaksudkan agar konsumen yang tidak mengerti atau tidak memahami bahasa asing tetap bisa menggunakannya, terutama dalam perdagangan produk impor telematika dan 
elektronika yang sangat diperlukan untuk memperlihatkan informasi dan cara menggunakan barang dalarn bahasa indonesia.

\section{SIMPULAN DAN SARAN}

\section{Simpulan}

Berdasarkan hasil analisis data, dapat disimpulkan bahwa dalam transaksi jual beli produk impor telematika dan elektronika harus dilandasi dengan hukum agar transaksi jual beli produk impor telematika dan elektronika tersebut aman dan dilindungi oleh hukum, karena dalam transaksi melibatkan 2 (dua) orang yaitu antara pelaku usaha dan konsumen diperlukannya membuat suatu perjanjian jual beli agar setelah terjadinya transaksi jika ada suatu masalah hal tersebut dapat dipertanggung jawabkan oleh konsumen atau pelaku usaha. Suatu perjanjian dapat terlaksana jika susah memenuhi syarat yaitu sepakat mereka yang mengikatkan diri, Kecakapan untuk membuat suaru perikatan/perjanjian, suatu hat tertentu, dan suatu sebab yang halal. Perlindungan hukum terhadap konsumen dalam transaksi jual beli produk impor telematika dan elektronika dalam hal terjadinya wanprestasi tersebut dapat menggunakan Undang-undang omor 8 Tahun 1999 tentang

Perlindungan Konsumen. Konsumen juga dapat memberikan perlindungan hukum terhadap konsumen agar tidak banyak konsumen yang dirugikan dikarenakan masih ada pelaku usaha yang melakukan kecurangan dan sanksi tersebut dapat dilihat pada pasal 19 dan dapat dikenakan sanksi administratif berupa penetapan ganti rugi yang paling banyak Rp. 200.000.000,00 (dua ratus juta rupiah).

\section{Saran}

Berdasarkan simpulan penelitian di atas, adapun saran yaitu baiknya pelaku usaha seharusnya memberikan informasi yang jelas, jujur dan benar terkait barang yang diperdagangkannya tersebut. Berbuat curang memang dapat mendatangkan keuntungan yang banyak akan tetapi dikarenakan ada aturan yang mengatur hal tersebut sebaiknya tidak dilakukan karena dapat memberikan risiko yang besar bagi kelangsungan usaha tersebut. Maka dalam kegiatan perdagangan berperilaku jujur sangat diharapkan Sebagai pelaku usaha bertindak baik dan jujur adalah suaru perbuatan yang sangat tepat. Selanjutnya kepada konsumen, jika ingin membeli suatu produk impor telematika dan elektronika diharapkan juga mencari informasi yang benar dan teliti dalam membeli barang agar setelah membeli barang tersebut konsumen tidak merasa dirugikan. Walaupun sudah ada hukum yang melindungi hak konsumen tetapi konsumen yang ceroboh dapat memberikan peluang bagi pelaku usaha untuk berbuat curang maka dari itu sebelum membeli suatu barang diharapkan agar lebih cermat dalam memilih dan teliti membeli suatu barang produk impor telematika dan elektronika tersebut.

\section{DAFTAR PUSTAKA}

Bambang, W. (2002). Penelitian Hukum dalam Praktek. Jakarta: Sinar Grafika.

Hamid, H. (2017). Hukum Perlindungan Konsumen Indonesia. Sah Media. Makassar.

Kamasa, F. (2014). Kejahatan Kerah Putih Kontraterorisme dan Perlindungan Hak Konstitusi Warga Negara dalam Bidang Ekonomi. Jurnal Konstitusi, 11(4), 782-804.

Miru, A. (2013). Prinsip-prinsip Perlindungan Hukum Bagi Konsumen di Indonesia. Jakarta. PT. Grafindo Persada.

Siti Amalia. (2020). UNDERGROUND ECONOMY Teori \& Catatan Kelam. Sumatra Utara. Yayasan Kita Menulis.

Sugiyono. (2013). Metode Penelitian Pendidikan Pendekatan Kuantitatif dan Kualitatif. Alfabeta.

Suparji. (2014). Pengaturan Perdagangan Indonesia. Jakarta. UAI Press.

Yahman. (2014). Karakteristik Wanprestasi \& Tindak Pidana Penipuan. Jakarta. Kencana.

Zulham. (2017). Hukum Perlindungan Konsumen. Jakarta. Prenada Media. 